\title{
BIBECHANA
}

A Multidisciplinary Journal of Science, Technology and Mathematics ISSN 2091-0762 (Print), 2382-5340 (Online)

Journal homepage: http://nepjol.info/index.php/BIBECHANA

Publisher: Research Council of Science and Technology, Biratnagar, Nepal

\section{Study of natural background radiation in Kathmandu Valley}

\author{
Parkash Pantha $^{1}$, Tanka Prasad Bhusal ${ }^{1}$, Buddha Ram Shah ${ }^{2}$, Rajendra Prasad Koirala ${ }^{1 *}$ \\ ${ }^{1}$ Central Department of Physics, Tribhuvan University, Kirtipur, Kathmandu \\ ${ }^{2}$ Nepal Academy of Science and Technology, Khumaltar, Kathmandu \\ "E-mail: rpkoirala@tucdp.edu.np \\ Article history: Accepted 05 November, 2018 \\ DOI: http://dx.doi.org/10.3126/bibechana.v16i0.21605 \\ This work is licensed under the Creative Commons CC BY-NC License. \\ https://creativecommons.org/licenses/by-nc/4.0/
}

\section{Abstract}

The study of natural background radiation dose at thirty two locations of Kathmandu valley has been done successfully using the instrument Radalert 100. The average dose rates and annual effective dose were measured. From the measurements, the least value of average dose rate was found to be $(22.3 \pm 3.9) \times 10^{-3} \mathrm{mR} / \mathrm{hr}$ for Sundhara and the greatest value of average dose rate was found to be $(37.7 \pm 7) \times 10^{-3} \mathrm{mR} / \mathrm{hr}$ for Budhanilkantha 3 . As per the annual effective dose, the least value was $0.391 \mathrm{mSv} / \mathrm{yr}$ for Sundhara and the greatest value was $0.661 \mathrm{mSv} / \mathrm{yr}$ for Budhanilkantha 3. The average annual effective dose of Kathmandu valley was $0.475 \mathrm{mSv} / \mathrm{yr}$ ranging from 0.391 $\mathrm{mSv} / \mathrm{yr}$ to $0.661 \mathrm{mSv} / \mathrm{yr}$. The values thus obtained were compared to the worldwide average value of annual effective dose, $0.48 \mathrm{mSv} / \mathrm{yr}$. Also, the obtained values were compared to the legal dose limit (annual effective dose), $1 \mathrm{mSv} / \mathrm{yr}$ set by International Commission on Radiological Protection (ICRP) for non-radiation workers and members of public. Among these thirty two locations, eight locations were chosen such that they had larger range of the observed dose rates. Those eight locations were re-observed. Further, Chi-square test was carried out to test whether the observed dose rates were following normal distribution or not. From the calculation, it was observed that the observed dose rates were following the normal distribution.

Keywords: Background radiation; Dose rate; Effective dose; Health hazard

\section{Introduction}

All the radiations have no deleterious effect on organisms. Non-ionizing radiations can only cause atoms to vibrate but not capable of create separate ions. However, ionizing radiation has the sufficient energy that can remove bound electrons from atoms, resulting in the ions capable of breaking chemical bonds. Both these types of radiation can be harmful to organisms but in general, ionizing radiation is far more harmful than the non-ionizing radiation [1,2]. When these radiations interact with the material they pass, the knock out electron from the electron shell that leaves the atom with a net positive charge. There are a lot of chances that the cell and even DNA molecule 
may be damaged. This can lead to the cancer but, it depends upon the amount of the radiation that is absorbed [3,4]. Alpha particles, beta particles, cosmic rays, gamma rays, X-rays carry energy enough to ionize atoms. Ionizing radiations cannot be detected directly by human senses. Devices like Geiger counters are used to detect it. Exposure to ionizing radiation may cause damage to living tissues, skin burns, radiation sickness and even death if the exposure is high [5].

Non-ionizing radiations such as visible light, microwave, radio waves, infrared, thermal radiation (heat), black body radiation etc. do not contain enough energy to ionize atoms. [6,2]. Human beings are exposed to the radiation every time and everywhere they go. During the formation of the earth about four billion years ago, it had contained many radioactive isotopes. The isotopes with short half-lives have decayed but that with long half-lives have remained till present. There are many naturally occurring radio nuclides that have half-lives of at least the same order of magnitude as that of estimated age of earth. The natural radioactive elements are present into the soil, rocks, air, food and drinking water. Thus, the natural environment works as a major source of radiation to which the human beings are exposed constantly. The ionizing radiation that comes mainly from the natural sources is called natural background radiation $[7,8]$.

People are exposed to radiation mainly from naturally occurring background radiation. Human beings receive average dose of $2.4 \mathrm{mSv}$ annually from background radiation. This dose rate depends upon the geology and altitude level where people live [9]. This absorption rate ranges from 1 to $10 \mathrm{mSv} / \mathrm{yr}$ and can be greater too. Around 140,000 people in Kerala and Madras states in India receive doses average over $15 \mathrm{mSv} / \mathrm{yr}$ from gamma radiation. This is the highest known level of background radiation that is affecting the considerable amount of population [10]. Also, the average exposure is about $40 \mathrm{mSv} / \mathrm{yr}$ in Brazil and Sudan. As far as the highest natural background radiation is concerned, the highest value is $800 \mathrm{mSv} / \mathrm{yr}$ which is on a Brazilian beach but, no people live there. There are different places known in the earth where natural background radiation is high. At Ramsar in Iran, about 200,000 people receive more than $10 \mathrm{mSv} / \mathrm{yr}$. Generally $\mathrm{U}^{238}, \mathrm{U}^{235}, \mathrm{Th}^{232}$ and to a lesser extent $\mathrm{K}^{40}$ and $\mathrm{Rb}^{87}$ produce external exposure to radiation. The radiation from these sources are of low doses but they could possess serious health problems [11-13].

Due to extreme hazardous health problems that may be caused by exposure from radiation, acceptable levels of radiation exposure and radiation doses have been set by different bodies based on the research in this fields. These bodies include National Academy of Science/National Research Council Advisory Committee on Biological Effect of Ionizing Radiation (BEIR), International Commission on Radiological Protection (ICRP), National Council on Radiation Protection and Measurement (NCRP), International Commission on Radiation Units and Measurements (ICRU), United Nations Scientific Committee on the Effects of Atomic Radiation (UNSCEAR), International Atomic Energy Agency (IAEA), World Health Organization (WHO) etc $[14,15]$.

The people in a certain location receive certain amount of radiation dose from the environment they live in. The reception of the dose may be due to external or internal cause. The amount of dose that they are exposed to may sometimes be hazardous. For the public to know about the type of environment they live in and for the awareness of doses that they receive from the environment they are living or being, this type of study or research work plays a vital role. This type of surveys can be useful for the appraisal of public dose rates as well as the reference for the further studies in the environmental radioactivity [7].

The outdoor-environmental monitoring exposure rate of radiation was measured in 200 randomly chosen regions in southwest of Iran using portable Geiger-Muller and scintillation detectors. The 
exposure dose rate was found to be $28.4 \mu \mathrm{R} / \mathrm{hr}$ and annual average effective equivalent dose was found to be $0.49 \mathrm{mSv}$. An overall population weighted average outdoor dose rate was calculated to be $49 \mathrm{nGy} / \mathrm{hr}$. It was higher than the world-wide mean value of $44 \mathrm{nGy} / \mathrm{hr}$, as reported by UNSCEAR in 1998, and was comparable to the annual effective dose equivalent of $0.38 \mathrm{mSv}$ $[16,14]$. A research work was carried out within the Younger Granite Province of Nigeria using the devices like solid scintillation counter and Geiger Muller tube. The study accounted that mean absorbed dose rates in air in the study area was $0.044 \pm 0.007 \mu \mathrm{Gy} / \mathrm{hr}$ within the basalts, $0.119 \pm$ $0.050 \mu \mathrm{Gy} / \mathrm{hr}$ for the basements rocks and $0.168 \pm 0.003 \mu \mathrm{Gy} / \mathrm{hr}$ within the younger granites, giving the average value of $0.106 \pm 0.002 \mu \mathrm{Gy} / \mathrm{hr}[17,18]$.

Similar type of research work was carried out in South Konkan, Maharashtra, India. The activity concentrations from the selected villages are found to be ranging from $24.78 \pm 0.14$ to $76.38 \pm 0.31$ $\mathrm{Bq} / \mathrm{kg}$ for $\mathrm{U}^{238}, 30.08 \pm 0.14$ to $96.18 \pm 0.31 \mathrm{~Bq} / \mathrm{kg}$ for $\mathrm{Th}^{232}$ and $105.34 \pm 0.24$ to $432.51 \pm 0.48$ $\mathrm{Bq} / \mathrm{kg}$ for $\mathrm{K}^{40}$. The average absorbed dose rate in air was calculated as $66.89 \mathrm{nGy} / \mathrm{hr}$. The annual effective dose rates were varied from $0.27 \mathrm{mSv} / \mathrm{yr}$ to $0.85 \mathrm{mSv} / \mathrm{yr}$ with an average of $0.49 \mathrm{mSv} / \mathrm{yr}$. The mean radium equivalent activity value for soil samples of South Konkan was $144.84 \mathrm{~Bq} / \mathrm{kg}$ $[19,20]$.

\section{Materials and Methods}

To measure the radiation dose rate at different locations of Kathmandu valley, Nepal, Radalert 100 was used. It is a health and safety instrument that measures alpha, beta and gamma radiations. It can be used to monitor the radiation level while working near radionuclide. It is a nuclear radiation monitoring device and counts ionizing events. The Radalert 100 uses a Geiger Muller tube (GM tube) to detect radiation. The GM tube generates a pulse of electrical current each time radiation passes through the tube and causes ionization. The Radalert 100 electronically processes these pulses to display the radiation level. Each pulse is electronically detected and registers as a count. The Radalert 100 displays the counts in different modes: counts per minute (CPM), milliroentgen per hour $(\mathrm{mR} / \mathrm{hr})$, total counts for a timed period. The diagram of the Radalert 100 is shown in figure 1.1 [21].

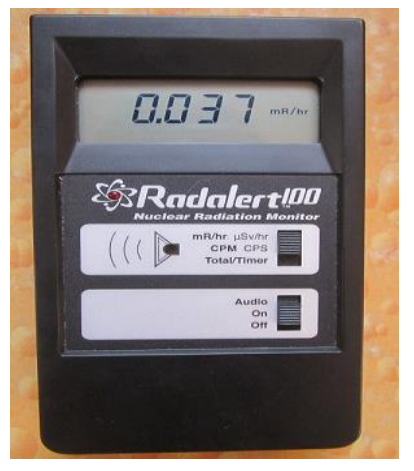

Fig. 1.1: Radalert 100

The position of each location at which radiation dose rate measured was recorded with the help of GPS system. The global positioning system (GPS) is a space-based satellite navigation system that provides location and time information in all weather conditions, anywhere on or near the earth. It is maintained by the United States Government and is freely accessible to anyone with a GPS receiver. During the study, Garmin 60 CS-GPS was used to measure the location coordinate of the observation point. 
During this study, different locations were marked out for the data collection at Kathmandu valley which were chosen randomly such that maximum areas of the Kathmandu valley were covered within the study. The GPS receiver was turned on and the location coordinates were noted. At the same time, Radalert 100 was also turned on. The mode switch of Radalert 100 was set to $\mathrm{mR} / \mathrm{hr}$. After the Radalert had turned on it does four-second system check and after one minute of turning it on, a short beep indicates that the enough information has been collected to ensure statistical validity. Then, the Radalert 100 was kept well above one meter from the ground of the observation point. GPS receiver was kept in parallel and very close with the Radalert 100. After all this, instantaneous readings of radiation dose were recorded for ten minutes at the interval of one minute and average value and range of radiation dose were noted. The location coordinates were also recorded using GPS receiver. Same observation processes were made for different locations but at different dates. The observations were done in thirty two locations of Kathmandu valley including two locations at Bhaktapur from March 18, 2016 to May 5, 2016 in between 12pm to 3pm. The average dose rate for a given location was calculated. Standard deviations of dose rate were calculated using the simple statistics. Eight locations were chosen that have large variations in the range of data observed. The observations were again performed in those locations. The Chi-square test was used to check whether there is a relationship between two categorical variables or not i.e. it is carried out to test whether the observed data fit the known theoretical distributions (such as normal or binomial distributions) or not. For Chi-square test, Chi-square statistic is used which is denoted by $x^{2}$ and defined as,

$$
\chi^{2}=\sum_{i=1}^{n} \frac{\left(O_{i}-E_{i}\right)^{2}}{E_{i}}
$$

where, $\mathrm{O}_{\mathrm{i}}$ is the observed frequency and $\mathrm{E}_{\mathrm{i}}$ is the expected frequency. If calculated value of Chi-square is less than the critical value of Chi-square for $v$ degree of freedom (i.e., $v=\mathrm{k}-1-\mathrm{m}$; $\mathrm{k}$ is the number of observation and $\mathrm{m}$ is population parameter from the sample data) at certain level of significance then, we could accept our null hypothesis at that level of significance otherwise, we reject it [22-24].

\section{Results and Discussion}

The dose rates of different locations of Kathmandu valley were obtained by using Radalert 100 . The average dose rate for a given location was calculated. The observations were done in thirty two different locations of Kathmandu valley. The observation points (locations) with their GPS coordinates, average dose rates, annual effective doses, standard deviation of dose rates and range are shown in Table 1. Variations of average dose rates at different location are shown in figure 1.2. Among thirty-two locations, eight such locations having large variation in the range of observed dose rates were re-observed. The locations were selected to be Kalimati, Baisdhara, Kirtipur, Satdobato, Chabahil, New Buspark Gongabu, Bansbari and Budhanilkantha 3. The dose rates reobserved at these locations are tabulated in Table 2. The frequency of the observed dose rates at Budhanilkantha was plotted against the observed dose rates which is shown in the figure 1.3 along with the Gaussian fit of the observed dose rates.

To test whether it is normally distributed with the mean $37.04 \times 10^{-3}$ and standard deviation $4.77 \times 10^{-3}$ or not, Chi-square test is carried out. The Chi-square value for the set of observed data is calculated to be 6.406 . For our observed data, having 8 degrees of freedom, the critical value of Chisquare at 0.05 level of significance is 15.507. Since, the calculated value of Chi-square is less than the critical value at 0.05 level of significance, we can conclude that there is a good fit i.e., the observed data 
are normally distributed with mean $37.04 \times 10^{-3}$ and standard deviation $4.77 \times 10^{-3}$. Similarly, frequency of observed dose rates at other re-observed locations are plotted against the dose rates, Gaussian curves are fitted and $x^{2}$ test is carried out at 0.05 level of significance. From $x^{2}$ test it is observed that the data are normally distributed at 0.05 level of significance.

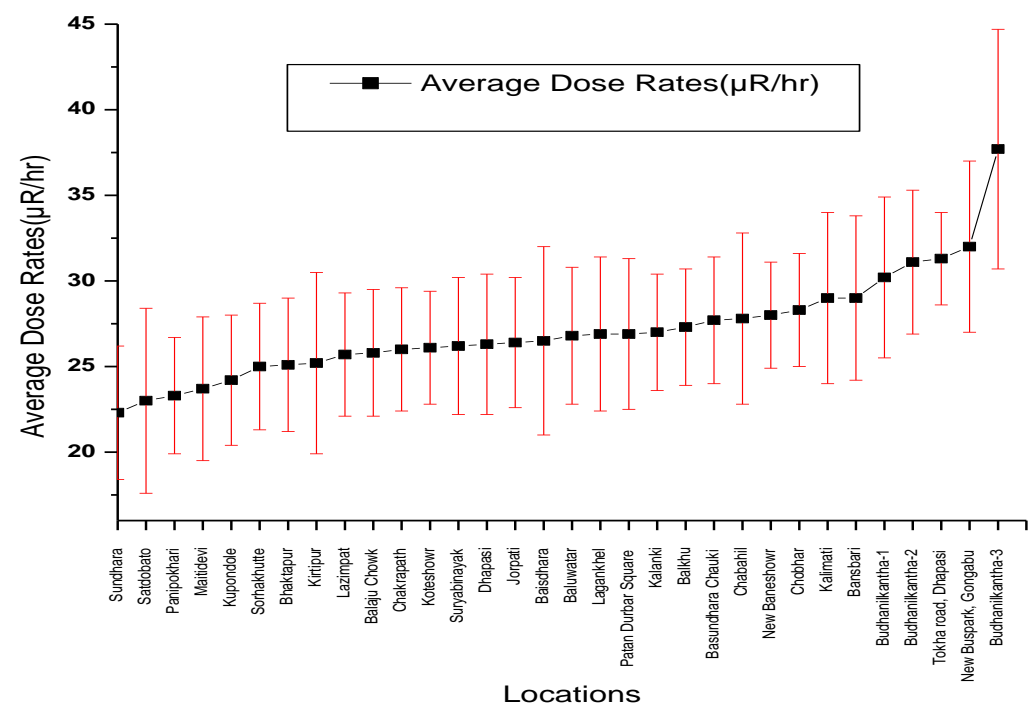

Fig. 1.2: A plot of average dose rates at different locations of Kathmandu valley.

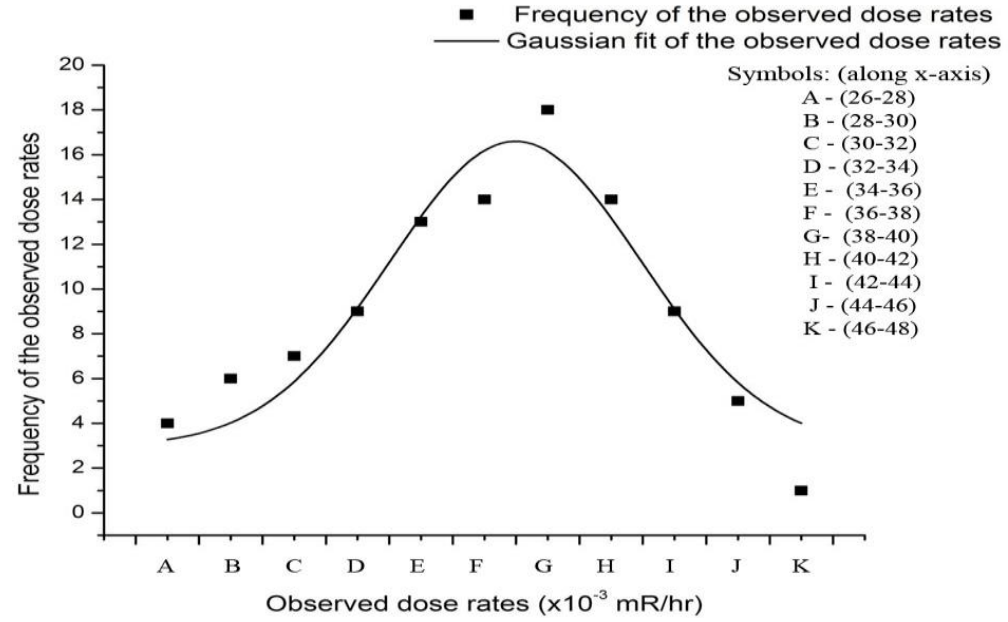

Fig. 1.3: Plot of Frequency of observed dose rates with respect to the observed dose rates for Budhanilkantha 3. The black spot mark indicates the frequency of observed dose rates and solid line indicates the Gaussian fit of the observed dose rates.

Further, peak value of observed dose rates at eight re-observed locations, where there was large variation in range of observed dose rate was studied. Maximum observed dose rates at eight reobserved locations are shown in figure 1.4. 
Parkash Pantha et al. / BIBECHANA 16 (2019) 187-195: RCOST p.192 (Online Publication: Dec., 2018)

Table 1: The observation points with their GPS coordinates, Average dose rates, standard deviation of dose rates, their range and annual effective doses at different locations of Kathmandu valley.

\begin{tabular}{|c|c|c|c|c|c|c|}
\hline S.N & Locations & GPS Coordinates & $\begin{array}{l}\text { Average Dose } \\
\text { Rates }(\mu \mathrm{R} / \mathrm{hr})\end{array}$ & $\begin{array}{l}\text { Standard } \\
\text { Deviation } \\
(\mu \mathrm{R} / \mathrm{hr})\end{array}$ & $\begin{array}{l}\text { Range } \\
(\mu \mathrm{R} / \mathrm{hr})\end{array}$ & $\begin{array}{l}\text { Annual effective } \\
\text { doses (mSv/yr) }\end{array}$ \\
\hline 1 & Sundhara & N $27^{0} 42^{\prime} 02.66^{\prime \prime}$ E $085^{0} 18^{\prime} 44.51^{\prime \prime}$ & 22.3 & 3.9 & $16-28$ & 0.391 \\
\hline 2 & Satdobato & $\begin{array}{l}\text { N } 27^{0} 39^{\prime} 30.0^{\prime \prime} \\
\text { E } 085^{0} \quad 19^{\prime} 31.2^{\prime \prime}\end{array}$ & 23.0 & 5.4 & $15-30$ & 0.403 \\
\hline 3 & Panipokhari & N $27^{0} 43^{\prime} 43.80^{\prime \prime}$ E $085^{0} 19^{\prime} 29.30^{\prime \prime}$ & 23.3 & 3.4 & $18-29$ & 0.408 \\
\hline 4 & Maitidevi & N $27^{0} 42^{\prime} 10.40^{\prime \prime}$ E $085^{0} 20^{\prime} 09.08^{\prime \prime}$ & 23.7 & 4.2 & $17-29$ & 0.415 \\
\hline 5 & Kupondle & N $27^{\circ} 41^{\prime} 12.45^{\prime \prime}$ E $085^{\circ} 19^{\prime} 01.12^{\prime \prime}$ & 24.2 & 3.8 & $19-30$ & 0.424 \\
\hline 6 & Sorhakhutte & N $27^{0} 43^{\prime} 08.30^{\prime \prime}$ E $085^{0} 18^{\prime} 34.00^{\prime \prime}$ & 25.0 & 3.7 & $18-30$ & 0.438 \\
\hline 7 & Bhaktapur & N $27^{0} 40^{\prime} 22.40^{\prime \prime}$ E $085^{\circ} 25^{\prime} 20.90^{\prime \prime}$ & 25.1 & 3.9 & $19-30$ & 0.440 \\
\hline 8 & Kirtipur & $\mathrm{N} 27^{0} 40^{\prime} 37.60^{\prime \prime}$ E $085^{\circ} 16^{\prime} 54.40^{\prime \prime}$ & 25.2 & 5.3 & $18-33$ & 0.442 \\
\hline 9 & Lazimpat & N $27^{0} 43^{\prime} 11.50^{\prime \prime}$ E $085^{0} 19^{\prime} 07.00^{\prime \prime}$ & 25.7 & 3.6 & $19-32$ & 0.450 \\
\hline 10 & Balaju Chowk & N $27^{0} 43^{\prime} 38.70^{\prime \prime}$ E $085^{\circ} 18^{\prime} 15.40^{\prime \prime}$ & 25.8 & 3.7 & $20-31$ & 0.452 \\
\hline 11 & Chakrapath & N $27^{\circ} 44^{\prime} 23.30^{\prime \prime}$ E $085^{\circ} 20^{\prime} 14.60^{\prime \prime}$ & 26.0 & 3.6 & $19-31$ & 0.456 \\
\hline 12 & Koteshowr & N $27^{0} 40^{\prime} 44.70^{\prime \prime}$ E $085^{\circ} 20^{\prime} 59.70^{\prime \prime}$ & 26.1 & 3.3 & $20-31$ & 0.457 \\
\hline 13 & Suryabinayak & N $27^{0} 39^{\prime} 57.40^{\prime \prime}$ E $085^{\circ} 25^{\prime} 24.90^{\prime \prime}$ & 26.2 & 4.0 & $20-32$ & 0.460 \\
\hline 14 & Dhapasi & N $27^{0} 45^{\prime} 10.80^{\prime \prime}$ E $085^{\circ} 19^{\prime} 34.90^{\prime \prime}$ & 26.3 & 4.1 & $21-33$ & 0.461 \\
\hline 15 & Jorpati & N $27^{0} 43^{\prime} 59.50^{\prime \prime}$ E $085^{\circ} 22^{\prime} 48.40^{\prime \prime}$ & 26.4 & 3.8 & $21-32$ & 0.463 \\
\hline 16 & Baisdhara & N $27^{\circ} 43^{\prime} 56.80^{\prime \prime}$ E $085^{\circ} 18^{\prime} 10.10^{\prime \prime}$ & 26.5 & 5.5 & $18-35$ & 0.464 \\
\hline 17 & Baluwatar & N $27^{0} 43^{\prime} 38.12^{\prime \prime}$ E $085^{0} 19^{\prime} 50.66^{\prime \prime}$ & 26.8 & 4.0 & $20-32$ & 0.470 \\
\hline 18 & Lagankhel & N $27^{\circ} 40^{\prime} 01.40^{\prime \prime}$ E $085^{\circ} 19^{\prime} 21.00^{\prime \prime}$ & 26.9 & 4.5 & $20-33$ & 0.471 \\
\hline 19 & $\begin{array}{l}\text { Patan Durbar } \\
\text { Square }\end{array}$ & N $27^{\circ} 40^{\prime} 22.23^{\prime \prime}$ E $085^{\circ} 19^{\prime} 29.52^{\prime \prime}$ & 26.9 & 4.4 & $19-32$ & 0.471 \\
\hline 20 & Kalanki & N $27^{\circ} 41^{\prime} 26.50^{\prime \prime}$ E $085^{\circ} 16^{\prime} 58.8^{\prime \prime}$ & 27.0 & 3.4 & $24-34$ & 0.473 \\
\hline 21 & Balkhu & N $27^{0} 41^{\prime} 07.20^{\prime \prime}$ E $085^{\circ} 17^{\prime} 43.20^{\prime \prime}$ & 27.3 & 3.4 & $23-33$ & 0.478 \\
\hline 22 & $\begin{array}{l}\text { Basundhara } \\
\text { Chauki }\end{array}$ & N $27^{\circ} 44^{\prime} 13.80^{\prime \prime}$ E $085^{0} 19^{\prime} 24.00^{\prime \prime}$ & 27.7 & 3.7 & $22-34$ & 0.485 \\
\hline 23 & Chabahil & $\mathrm{N} 27^{0} 43^{\prime} 37.30^{\prime \prime}$ E $085^{0} 20^{\prime} 21.10^{\prime \prime}$ & 27.8 & 5.0 & $19-35$ & 0.487 \\
\hline 24 & $\begin{array}{l}\text { New } \\
\text { Baneshowr }\end{array}$ & N $27^{0} 41^{\prime} 18.40^{\prime \prime}$ E $085^{\circ} 20^{\prime} 07.40^{\prime \prime}$ & 28.0 & 3.1 & $24-32$ & 0.491 \\
\hline 25 & Chobhar & N $27^{0} 39^{\prime} 44.70^{\prime \prime}$ E $085^{\circ} 17^{\prime} 22.20^{\prime \prime}$ & 28.3 & 3.3 & $24-33$ & 0.496 \\
\hline 26 & Kalimati & $\mathrm{N} 27^{0} 41^{\prime} 53.19^{\prime \prime}$ E $085^{\circ} 17^{\prime} 57.10^{\prime \prime}$ & 29.0 & 5.0 & $20-36$ & 0.508 \\
\hline 27 & Bansbari & $\mathrm{N} 27^{\circ} 44^{\prime} 48.90^{\prime \prime}$ E $085^{\circ} 20^{\prime} 38.50^{\prime \prime}$ & 29.0 & 4.8 & $23-38$ & 0.508 \\
\hline 28 & $\begin{array}{l}\text { Budhanilkantha } \\
1\end{array}$ & $\mathrm{~N} 27^{0} 46^{\prime} 41.22^{\prime \prime}$ E $085^{\circ} 21^{\prime} 44.21^{\prime \prime}$ & 30.2 & 4.7 & $22-35$ & 0.529 \\
\hline 29 & $\begin{array}{l}\text { Budhanilkantha } \\
2\end{array}$ & N $27^{0} 46^{\prime} 47.20^{\prime \prime}$ E $085^{\circ} 21^{\prime} 27.90^{\prime \prime}$ & 31.1 & 4.2 & $26-38$ & 0.545 \\
\hline 30 & $\begin{array}{l}\text { Tokha road, } \\
\text { Dhapasi }\end{array}$ & N $27^{0} 44^{\prime} 42.40^{\prime \prime}$ E $085^{0} 19^{\prime} 23.20^{\prime \prime}$ & 31.3 & 2.7 & $27-35$ & 0.548 \\
\hline 31 & $\begin{array}{l}\text { New Buspark, } \\
\text { Gongabu }\end{array}$ & N $27^{\circ} 44^{\prime} 15.26^{\prime \prime}$ E $085^{\circ} 18^{\prime} 58.20^{\prime \prime}$ & 32.0 & 5.0 & 24-39 & 0.561 \\
\hline 32 & $\begin{array}{l}\text { Budhanilkantha } \\
3\end{array}$ & N $27^{0} 46^{\prime} 53.80^{\prime \prime}$ E $085^{\circ} 21^{\prime} 15.20^{\prime \prime}$ & 37.7 & 7.0 & $26-45$ & 0.661 \\
\hline
\end{tabular}


Table 2: A list of observed dose rates and their corresponding frequencies at Budhanilkantha 3.

\begin{tabular}{|c|c|}
\hline Range of observed dose rates $\left(\times 10^{-3} \mathrm{mR} / \mathrm{hr}\right)$ & Frequency \\
\hline $26-28$ & 4 \\
\hline $28-30$ & 6 \\
\hline $30-32$ & 7 \\
\hline $32-34$ & 9 \\
\hline $34-36$ & 13 \\
\hline $36-38$ & 14 \\
\hline $38-40$ & 18 \\
\hline $40-42$ & 14 \\
\hline $42-44$ & 9 \\
\hline $44-46$ & 5 \\
\hline $46-48$ & 1 \\
\hline
\end{tabular}

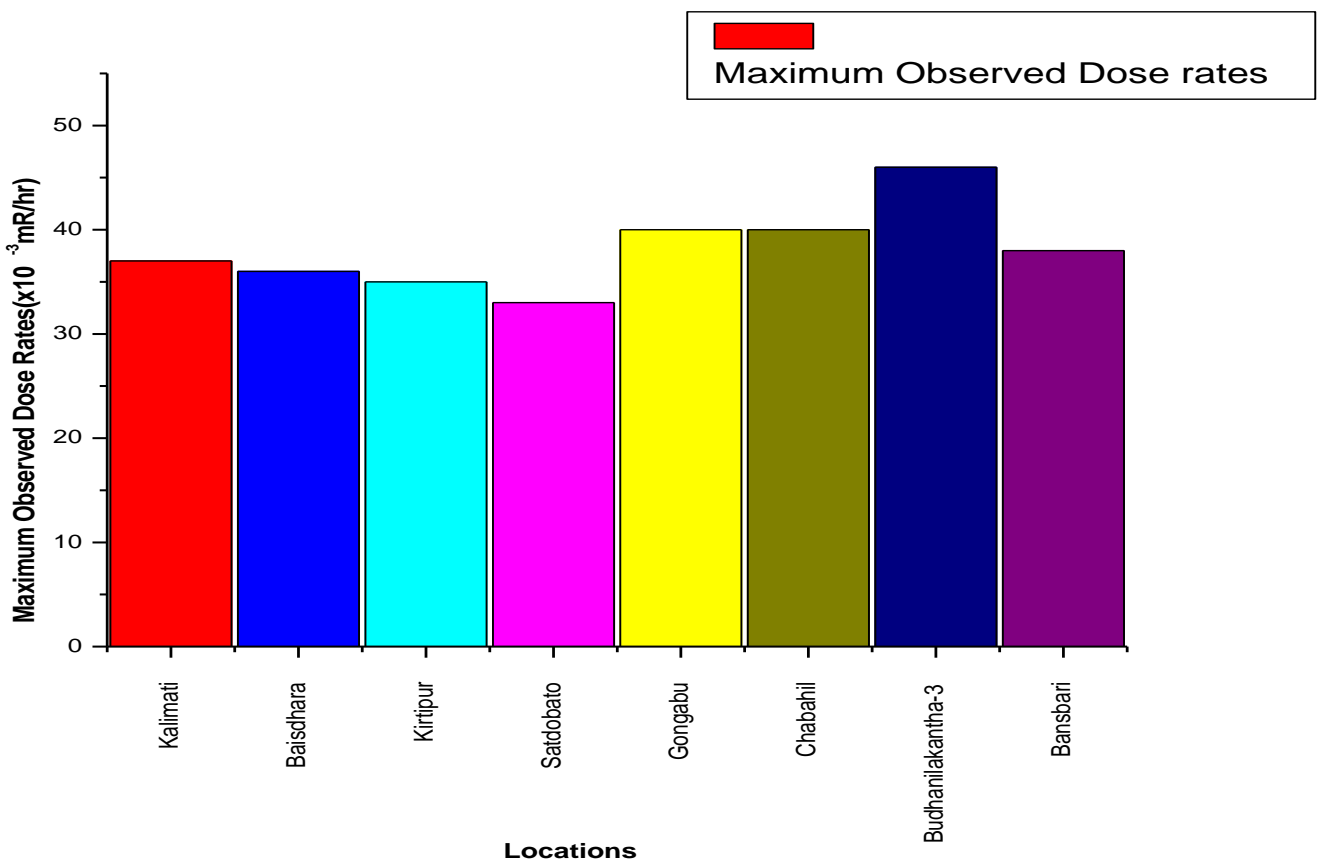

Fig. 1.4: Maximum observed dose rates at different locations where maximum variation in range of dose rate was observed.

\section{Conclusion}

Natural background radiation dose at different locations of Kathmandu valley was studied. Altogether thirty two locations were considered under the study. Among these locations, the least value of average dose rate was found to be $(22.3 \pm 3.9) 10^{-3} \mathrm{mR} / \mathrm{hr}$ for Sundhara and the greatest value of average dose rate was $(33.7 \pm 7.0) 10^{-3} \mathrm{mR} / \mathrm{hr}$ for Budhanilkantha 3. Similarly, the least and greatest value of annual effective dose were $0.391 \mathrm{mSv} / \mathrm{yr}$ and $0.661 \mathrm{mSv} / \mathrm{yr}$ for Sundhara and 
Budhanilkantha 3 respectively. Study shows that Budhanilkantha 3 has highest radioactivity compared to that of others.

Also, among the observed locations, the locations having large variation in range of observed dose rates were re-observed. For each location, the Chi-square test was carried out to test whether the observed dose rates follow normal distribution or not at 0.05 level of significance. The Chi-square value, calculated for each location, appeared to be less than that of critical value of Chi-square at 0.05 level of significance. We concluded that the observed dose rates follow normal distribution.

As we turn around the globe, the worldwide average value of annual effective dose is $0.48 \mathrm{mSv} / \mathrm{yr}$, with its value lying within the range of $0.3 \mathrm{mSv} / \mathrm{yr}$ to $0.6 \mathrm{mSv} / \mathrm{yr}$ for individual countries. Also, if we look upto the legal dose limit (annual effective dose) set by ICRP for non-radiation workers and members of public, it accounts to be $1 \mathrm{mSv} / \mathrm{yr}$. From the study findings, we observed that the average annual effective dose of Kathmandu valley is $0.475 \mathrm{mSv} / \mathrm{yr}$ ranging from $0.391 \mathrm{mSv} / \mathrm{yr}$ to $0.661 \mathrm{mSv} / \mathrm{yr}$. If we look at the observation locations carefully, about eleven locations have greater annual effective dose than that of worldwide value. Among them, Budhanilkantha 3 has the highest annual effective dose. These values of annual effective dose are less than that of legal dose limit for nonradiation workers and members of public set by ICRP. Hence, the natural exposure level at Kathmandu valley is not hazardous to the people in the study regions.

\section{References}

[1] T. D. Luckey et al. Hormesis with ionizing radiation, CRC Press Boca Raton, 1980.

[2] N. G. Kwan-Hoog. Non-ionizing radiations-sources, biological effects, emissions and exposures, In Proceedings of the international conference on non-ionizing radiation at UNITEN, 2003.

[3] M. Mifune, T. Sobue, H. Arimoto, Y. Komoto, S. Kondo, and H. Tanooka, Cancer mortality survey in a spa area (Misasa, Japan) with a high radon background, Japanese journal of cancer research 83(1) (1992) 1-5.

[4] United Nations, Scientific Committee on the Effects of Atomic Radiation, Sources and effects of ionizing radiation: sources, volume 1, United Nations Publications, 2000.

[5] A. H Elgazzar and N. Kazem, Biological effects of ionizing radiation, In The pathophysiologic basis of nuclear medicine, pages 715-726, Springer, 2015.

[6] O. Erogul, E. Oztas, I. Yildirim, T. Kir, E. Aydur, G. Komesli, H. Cem Irkilata, M. K. Irmak, and A. F. Peker, Effects of electromagnetic radiation from a cellular phone on human sperm motility: an in vitro study, Archives of medical research, 37(7) ( 2006) 840-843.

[7] P. Alaei. Introduction to health physics, Medical Physics 5(12) ( 2008) 5959- 5959.

[8] United Nations Scientific Committee on the Effects of Atomic Radiation et al. Sources, effects and risks of ionizing radiation, 1988.

[9] A. D. Wrixon, New icrp recommendations. Journal of radiological protection, 28(2) (2008) 161.

[10] M. S. Reddy, C. G. Reddy, P. Y. Reddy, and K. R. Reddy, Study of natural background gamma radiation levels in hyderabad and its surroundings, andhrapradesh, India, 2010.

[11] A. S. Alencar and A. C. Freitas. Reference levels of natural radioactivity for the beach sands in a brazilian southeastern coastal region, Radiation Measurements 40(1) (2005) 76-83.

[12] R. Veiga, N. Sanches, R. M. Anjos, K. Macario, J. Bastos, M. Iguatemy, J. G. Aguiar, A. M. A. Santos, B. Mosquera, C. Carvalho, et al. Measurement of natural ra-dioactivity in Brazilian beach sands, Radiation measurements 41(2) ( 2006) 189-196.

[13] A. K. Sam, M. M. O. Ahmed, F. A. El Khangi, Y. O. El Nigumi, and E. Holm, Assessment of terrestrial gamma radiation in Sudan, Radiation protection dosimetry 71(2)(1997) 141-145.

[14] W. R. Hendee. Medical imaging physics, John Wiley \& Sons, 2003. 
[15] M. Sperrin, G. Gillmore, and T. Denman, Radon concentration variations in a mendip cavecluster. Environmental Management and Health 12(5) ( 2001) 476-482.

[16] J. E. Martin. Physics for radiation protection: a handbook, John Wiley \& Sons, 2006.

[17] A. O. Solomon, A study of natural radiation levels and distribution of dose rates within the younger granite province of Nigeria, $\mathrm{PhD}$ thesis, 2006.

[18] L. E Wahl. Environmental radiation-a fact sheet, Health Physics Society, Lawrence:Berkeley National Laboratory, 2010.

[19] F Knoll Glenn et al. Radiation detection and measurement, John Wiley \& Sons, New York, 1989.

[20] S. J. Dhawal, G. S. Kulkarni, and S. H. Pawar, Terrestrial background radiation studies in south konkan, maharashtra, India, Int. J. Radiat. Res. 11(4) ( 2013) 263- 270.

[21] N. R. Monitor and O. Manual, "Radalert 100."

[22] R. V. Hogg and A. T. Craig, Introduction to mathematical statistics, (5th edition), Upper Saddle River, New Jersey: Prentice Hall, 1995.

[23] H. O. Lancaster and E. Seneta, Chi-square distribution, Encyclopedia of biostatistics, 2, 2005.

[24] J. S. Milton and J. C. Arnold, Schaum's Outline of Introduction to Proba-bility \& Statistics: Principles \& Applications for Engineering \& the Computing Sciences, McGraw-Hill Higher Education, 1994. 